\title{
Measuring the Impact of Background Checks on Reducing Crime in Higher Education
}

\author{
Stephanie F. Hughes ${ }^{1}$, Teressa L. Elliott ${ }^{1} \&$ Margaret Myers ${ }^{1}$ \\ ${ }^{1}$ Haile/US Bank College of Business, Northern Kentucky University, Highland Heights, Kentucky, USA \\ Correspondence: Stephanie F. Hughes, Department of Management, Haile/US Bank College of Business, \\ Northern Kentucky University, One Nunn Drive, 328 Business Center Building, Highland Heights, KY 41099, \\ USA. Tel: 859-572-1389. E-mail: hughesst@nku.edu
}

\author{
Received: July 22, 2014 Accepted: July 31, 2014 Online Published: October 29, 2014 \\ doi:10.5539/par.v3n2p154 URL: http://dx.doi.org/10.5539/par.v3n2p154
}

\begin{abstract}
Responding to a variety of constituent pressures in recent years, a number of states in the U.S. have enacted legal requirements that their public universities conduct background checks on prospective new employees. The assumption behind these mandates is that background checks reduce crime on campus. This study will attempt to test that assumption by utilizing data gathered under the reporting requirements of the Clery Act, from four states which have passed legislation requiring background checks: Arizona, Kentucky, Utah, and Wisconsin. The results of this preliminary study suggest that states that have either legislated or mandated the use of criminal background checks on new hires in university environments have not experienced a reduction in Clery Act incidents on their campus when comparing their pre-background check activity with their post-background check implementation. When the quality of the background check being utilized is included in the analysis, the results continue to show that there is no change in the Clery Act incident levels when comparing their pre-background check activity with their post-background check implementation.It is important to note that, prior to the launch of this study, we did not find any specific references to suggest that Clery Act reports were primarily capturing student level criminal data so we were surprised to find that background checks had no impact at all on campus crime levels.So, the results of this study may inadvertently provide support to the recognition that the Clery data tend to reflect only student-level criminal activity whereas the background checks analyzed in this report were applied only to new hires or transfers to new positions. While student employees were often covered in these policies, the general student population was not, setting the stage for a necessary follow-up study that looks at Clery Act data in universities that are utilizing background checks in their admissions practices to see if there is a measureable impact on their Clery campus crime statistics.
\end{abstract}

Keywords: background checks, Clery data, campus crime, higher education, empirical

\section{Introduction}

Public and legislative concerns about campus safety date back over many years, but were first highlighted in federal legislation in the"Crime Awareness and Campus Security Act of 1990," known as the Clery Act.As described in more detail below, the Clery Act mandates the reporting of crime statistics on campus.Employment criminal background checks are a more recent and controversial tool for institutions of higher education (IHEs) to provide a safe environment for students and employees.Many administrators at universities contend they are doing a great deal to ensure the safety of their campus communities, but must work realistically within budget constraints.Moreover, some faculty and administrators believe that background checks represent an unnecessary invasion of privacy. The American Association of University Professors, for example, argues that the type of information background checks reveal is not worth either the financial cost or the invasion of privacy that comes with implementing such policies (AAUP, 2004).On the other hand, state lawmakers have increasingly become more proactive by proposing and passing legislation requiring their state institutions of higher education to begin checking the criminal backgrounds of new hires, and in some cases, those of incoming students.This juxtaposition of legislative requirements, budgetary constraints and organizational resistance suggests that there is a need to investigate whether required background checks have actually worked to make campuses safer.This study attempts to measure the effectiveness of background check practices at reducing the rate of criminal activity on college campuses. 


\section{The Clery Act Legislation}

In 1986 Jeanne Ann Clery was raped and murdered in her college dormitory room by a fellow student at Lehigh University.According to the Clery Center for Security on Campus website, unbeknownst to Jeanne's parents, Lehigh University had a total of thirty-eight violent criminal incidents on campus in the prior three years alone that were not publicized (www.securityoncampus.org).After the murder of their daughter, the Clerys pushed for legislation requiring colleges to collect and publish statistics of criminal activity on their campuses.In 1990, the Jeanne Clery Act was passed into law.

As detailed on the Clery Website, the Clery Act was passed because Congress found that while crime on college campuses had steadily risen, comprehensive data on campus crimes did not exist.Congress also found that only 352 colleges and universities voluntarily provided crime statistics directly through the Uniform Crime Report of the Federal Bureau of Investigation while other colleges and universities reported in a manner that did not permit campus statistics to be separated. Congress acknowledged that several state legislatures had adopted or were considering legislation to require reporting of campus crime statistics, but the bills were not uniform in their requirements and standards (www.securityoncampus.org).(See Appendix A for a full overview of the Clery Act requirements.)

The Clery Act affects all post-secondary institutions which receive Title IV Funding (i.e. those that participate in federal student aid programs). Congress, in the 1990 Act, required each eligible institution to collect certain information with respect to campus crime statistics and campus security policies, and to "distribute...to all current student and employees and to any applicant for enrollment or employment upon request, an annual security report" (www.securityoncampus.org). The data are reported annually by schools to the U.S. Department of Education which maintains these data on its website under the Campus Crime Statistics section.

\section{Campus Crime}

\subsection{General Crime Statistics}

According to the Campus Crime Statistics website of the U.S. Department of Education, overall levels of crime on campus have been dropping.Compiling the latest aggregate figures available, overall reported crime on campus, including both two- and four-year colleges and universities, has dropped approximately $17 \%$ from 2007 to 2009 (Table 1).Even more encouraging, students are at a lower risk from violent and property crime victimization than are their non-student peers in the same age range (18-24) (Hart, 2003, 2007).

Table 1. Criminal activities on college campuses from 2007-2009 (On-campus only)

\begin{tabular}{lrrr}
\hline & $\mathbf{2 0 0 7}$ & $\mathbf{2 0 0 8}$ & $\mathbf{2 0 0 9}$ \\
\hline Murder & 45 & 13 & 17 \\
Negligent Manslaughter & 3 & 3 & 0 \\
Forcible Sex Offenses & 2736 & 2670 & 2590 \\
Non-Forcible Sex Offenses & 42 & 36 & 72 \\
Robbery & 1932 & 1939 & 1865 \\
Aggravated Assault & 2772 & 2689 & 2675 \\
Burglary & 30265 & 29594 & 24069 \\
Motor Vehicle Theft & 4925 & 4370 & 4270 \\
Arson & 785 & 708 & 647 \\
Totals & 43,505 & 42,022 & 36,205 \\
\hline
\end{tabular}

Source: 2013 U.S. Department of Education Crime Statistics Online

While all types of crime categories captured have declined in total numbers, the rates of criminal activity are still alarmingly high and recent high profile cases, such as the sexual abuse case at Penn State (Pearson, 2013) and the murder of a medical student at the University of Michigan (Jacobs, 2013), have only reinforced the view of many that much more needs to be done to address the problem of crime on campus. While this study is focused on the use of background checks as a mitigating factor in the level of campus criminal activity, we must first understand the overall trends, demographics and contributing factors associated with criminal activity in a 
campus setting before we can even begin to assess the effectiveness of background checks of potential employees.

Current Clery Act reporting requirements focus the bulk of the reporting data on the location of and the actual type of crime that is being reported.As is evidenced by Table 1, most of the on-campus crime reports focus on property crimes and this trend has been found to be consistent across time (U.S. Department of Education Crime Statistics Online). While the numbers captured above represent on-campus crime, it has been estimated that a full $93 \%$ of crimes occur off-campus (Baum \& Klaus, 2005), and many actual crimes that do occur never get reported for many different reasons.Sloan et al.'s (1997) study of 3,400 college students and their victimization reporting practices found that more than $75 \%$ of crimes identified by these students were not reported to campus police, and included both violent and property crimes in equal measure. Hart's (2003) violent victimization study also found that approximately only $34 \%$ of all violent crimes were reported to police, lending statistical support to the findings of later survey studies that suggest that college students, in general, are less inclined to, and therefore, actually report violent and property crimes to the police less than their non-student peers in the general population (Baum \& Klaus, 2005). Fisher et al. (2002) found that campus crime statistics are underreported because they do not take into account all types of crime such as larceny, which tends to have significantly higher incident numbers on college campuses.Carr (2007) indicated that the significant underreporting of crimes on campus occurred because crimes of larceny, theft, threats, harassment and vandalism were not included in required Clery Act incident reporting guidelines.So, while these crimes may be reported to campus administrators, they are not captured in official Clery Act statistics and so the official "crime rates" for college campuses may be unintentionally bereft of the true volume of criminal activities.

\subsection{Location of Reported Campus Crimes}

Because the majority of college students do not actually live on campus, Carr (2007) suggested that these students are actually made more vulnerable to crime than the on-campus numbers suggest, primarily due to where they live in proximity to campus (Fleenor, 2009). Hart (2007), in a national crime victimization survey administered to college students,found thatoff-campus violence among college students was 20 times the rate of on-campus victimization.Baum and Klaus's (2005) violent victimization survey of college students found that $90 \%$ of violent crimes experienced by students occurred away from campus and were greater during nighttime hours than during the day (Fisher et al., 2002; Hart 2007). Since location of the crime will also play a role in the actual reporting of the crime to authorities, campus crime statistics are also likely to be underreported due, in large part, to where the crime actually occurs. We can actually see this if we look at comparable Clery Act incident reports identified as occurring off campus from 2007-2009 (Table 2) versus the data previously reported in Table 1.The numbers are significantly lower than the on-campus numbers by a factor greater than four.

Table 2. Criminal activities on college campuses from 2007-2009 (Off-campus only)

\begin{tabular}{lrrr}
\hline & $\mathbf{2 0 0 7}$ & $\mathbf{2 0 0 8}$ & $\mathbf{2 0 0 9}$ \\
\hline Murder & 21 & 39 & 14 \\
Negligent Manslaughter & 4 & 2 & 4 \\
Forcible Sex Offenses & 742 & 600 & 694 \\
Non-Forcible Sex Offenses & 19 & 23 & 27 \\
Robbery & 3024 & 2601 & 2784 \\
Aggravated Assault & 2441 & 2138 & 2306 \\
Burglary & 2583 & 2342 & 2212 \\
Motor Vehicle Theft & 2696 & 2359 & 2212 \\
Arson & 130 & 112 & 94 \\
Totals & 11,660 & 10,216 & 10,347 \\
\hline Sourc:
\end{tabular}

Source: 2013 U.S. Department of Education Crime Statistics Online

\subsection{The "Who" of Campus Crime}

It has been broadly assumed by many, including many campus administrators, parents and students, that the actual criminal activity, whether reported or not, is caused by individuals who are not associated with the campus 
in any way.The "who" behind the crime has proven more difficult to uncover because the current Clery Act reporting requirements do not require campus police to categorize the relationship of the perpetrator to the campus community.In Baum and Klaus's (2005) violent victimization of college students' survey, they found that $58 \%$ of crimes committed against students were committed by strangers, but these numbers differed dramatically by the type of crime committed.Among victims of rape or sexual assault, they were four times more likely to be attacked by someone they knew; findings that have previously been reported for victims of stalking as well (Fisher, et al., 2002). Finally, in a meta-analyses study comparing sexual assault prevalence in military academies and universities, Brubaker (2009) found that in both types of environments, "victims and perpetrators tend to be peers, if not intimates or acquaintances."

\section{Clery Act Studies}

\subsection{Clery Act and the Under-Reporting of Campus Crime}

Despite the significant volume of research that has emerged over the past decade and a half on the nature and correlates of campus crime, there have been just a few studies that have incorporated the campus crime statistics compiled under the Clery Act legislation as the basis for their analysis.Fisher, et al., (2003) analyzed whether the Clery Act had achieved accuracy in the reporting of both the volume of and the nature of crime statistics that helped communicate the relative safety level of college campuses. Their findings suggest that the Clery Act statistics compiled by universities actually underestimate the level of criminal activity occurring on campuses because much of the criminal activity that does occur, especially crime that involves students, goes unreported to campus officials by students. The authors cite many reasons for why a significant level of crimes go unreported including: students did not think the crime was serious enough, fear of reprisal, the perpetrator was known to the victim, there was no proof that the incident had happened, and there was concern expressed by victims that they did not want family to know about the incident (Fisher et al., 2003). As such, the authors conclude that the Clery Act "provides very little accurate information that students, their parents and staff can use to make informed decisions about the relative safety of a college campus" (Fisher et al., 2003). Nobles, et al., (2010) utilized geospatial mapping capability in their analysis of Clery Act data to examine the offending patterns of students and non-students occurring both on and off-campus at a large southeastern university.Their findings suggest that Clery Act reports are significantly underestimated because they do not capture the criminal activity that occurs just off-campus, but proximate to the university's boundaries.Nobles et al. (2010) profiled those included in these statistics:

Whites, females, and younger arrestees were significantly more likely to be college students than non-students, suggesting that these groups may offend disproportionately on-campus while others (non-Whites, males, and older individuals) offend off-campus. Also, on-campus arrest was positively and significantly associated with college student arrests, indicating that college students were more likely to be arrested on-campus (p.18).

These findings suggest college students are responsible for the majority of the arrests that are occurring on campus, but these arrest numbers actually under-represent the total amount of criminal activity that is actually occurring within the entire campus community.

\subsection{Clery Act and Increased Reporting of Campus Crime}

While there appears to be some degree of consensus that various factors influence the underreporting of the actual level of campus crime, few have suggested that the Clery Act could actually contribute to an increase in campus crime reporting. Brinkley and Lester (2003) did, however, by investigating campus crime in five state universities in Missouri utilizing the institutions' Clery Act reports alongside the FBI's Uniform Crime Reporting (UCR) statistics for universities and colleges over a three-year period from 1997-1999. In a comparison of the data from both of these sources, the authors found that while the number of campus-specific Clery Act and UCR reports for robbery, burglary, aggravated assaults, motor vehicle theft, and arson were generally the same, the Clery Act statistics for forcible sex offenses were significantly higher than what the UCR data suggest.The authors conclude that the Clery Act "appears to have had a positive influence on both the reporting of crimes on campuses and the publication of information about crimes."

Fleenor (2009) examined the relationship between a residential college system, where on-campus housing is structured into residential colleges or house systems, and campus crime as a way to assess the possible safety benefits of residential housing systems over more traditional dormitory style housing options. According to Fleenor (2009), a residential housing system "typically includes a master and dean, a body of fellows (senior members) and a body of a several hundred students for each house or college." Utilizing Clery Act statistics for a single year (2006) and covering a total of two groups of 27 matched pair institutions, the results indicated that 
there were fewer aggravated assaults overall on campus and in residence halls with institutions that had residential college systems than those without these types of systems.Conversely, there were statistically significant fewer arrests for on-campus liquor law violations in the non-residential college systems versus their residential counterparts. The author acknowledged utilizing Clery Act reports as a representative instrument of the actual levels of campus crime was limited by a variety of factors, including the fact that the reports do not indicate who is actually responsible for the crimes or who is being targeted. The reports also do not capture crimes against students at off-campus locations and, finally, the reports do not include statistics for the amount of larceny, theft, harassment and vandalism (Carr, 2007; Fleenor, 2009).

\subsection{Impact of Clery Data on Decision-Making}

In addition to the underreporting issues associated with Clery reports, there is evidence that existing reports fail to actually influence student behavior when it comes to choosing a university. Gregory and Janosick, citing a study by Janosick and Gehring, found that $92 \%$ of students did not refer to Clery Act reports when choosing their university or college (Gregory \& Janosick, 2002). For those students who are already on campus, sixty percent of students received campus crime information from other sources such as articles and flyers rather than from the published campus Clery reports (Gregory \& Janosick, 2002). In a study conducted by Gregory and Janosick, campus law enforcement officers were surveyed and over $43 \%$ said that the Act improved campus law enforcement policies and procedures, but only $10 \%$ thought the Act reduced campus crime and $90 \%$ thought the Clery reports did not influence student behavior (Gregory \& Janosick, 2002). The authors also found that only 25\% of students were aware of the Clery Act reports and had read a report (Gregory \& Janosick, 2002). The authors state that due to these problems with the Clery Act, focus on the Act should not be on the categories of crimes, geographical areas universities should include in the report, and which programs should be covered by the Act as is commonly discussed, but instead, the focus should be on improving the Act by ensuring our campuses are safer (Gregory \& Janosick, 2002). The authors state that "educational efforts, both programs and incidental-crime information, do appear to be more effective than the crime reports at changing behavior" (Gregory \& Janosick, 2002). Each of these studies reinforce the view of many experts that while the safety reports generated by universities to comply with the Clery Act fail to provide a completely accurate picture of the safety and security profile on U.S. campuses, it is not necessarily because schools are not accurately reporting the crime that does take place and is reported to campus administrators. Instead, it is likely due to a number of other, often personal and sometimes systemic, factors that contribute to the under-reporting of the total amount of actual crime associated with and occurring on U.S. college campuses.

\section{Background Checks}

\subsection{Definition}

The use of the term "background check" may refer to the verification of multiple types of information, including the documentation of educational qualifications, checking personal and professional references, requiring drug tests, checking criminal history, verifying social security number and I-9 status, and so on. By whatever mechanism, employers have a legal duty under the doctrine of "negligent hiring" to protect their employees and customers from the risk posed by potentially dangerous individuals (Kahland v. Villarreal, 2006, Note 1). For the purposes of this paper, we are only interested in criminal background check processes and so for the rest of this paper, our reference to background check processes is assumed to mean the criminal background check process.

Most organizations, including IHEs, have historically used some form of background checks, usually focused on verification of professional qualifications. However, in the last decade there has been a divergence between hiring practices in the educational sector and those in other employment sectors, in which criminal background checks have become relatively commonplace, especially since 2001. Connerley et al. (2001) surveyed 114 public employers in the U.S. and found that of the 62 responding agencies $(50 \%)$, all of the respondents performed criminal checks on at least some of the prospective employees and 31 of $62(50 \%)$ performed criminal checks on all of their employees. That rate has steadily increased at about $12 \%$ per year since then. A survey conducted in 2007 of human resources professionals indicated $85.9 \%$ run criminal checks of new hires (Dickerson fn2).

\subsection{Conflicting Legal Requirements}

Background checks are not unalloyed, and employing organizations must mediate conflicting legal requirements. On the one hand, organizations must protect themselves from the potential liabilities of "negligent hiring"; they must also protect themselves from risking defamation and/or discrimination in employment practices. Waska (2007) highlighted this conflict that human resource managers face when they attempt to conduct reference checks on prospective employees.Most legal advocates suggest that employers obtain as much information as possible to diminish the possibility of negligent hiring.Simultaneously, employers are advised to limit the 
amount of information they release on former employees to reduce the possibility of civil claims resulting from defamation or invasion of privacy. Waska concludes that the solution to overcoming this dilemma includes instituting uniform procedures for responding to requests for information while designing thorough waivers which would provide authorization for these types of inquiries for all new hires.

Schloss and Lahr (2008) highlighted additional types of risks that employers assume with background checks including possible Title VII civil rights violations resulting in "disparate impact" or "disparate treatment" on certain minority groups, FCRA violations resulting from the misuse of criminal records, and Occupational Safety and Health Act (OSHA) civil liabilities resulting from an employer's failure to provide a safe workplace for their employees (Notes 2, 3, 4).

Despite the countervailing legal pressures with respect to privacy and discrimination, criminal background checks are likely to continue as standard employment practice in non-educational settings. Higher education has been slower in its adoption of criminal background checks. Historically, most institutions of higher education performed such background checks only on a handful of key administrative personnel such as those with access to financial resources and records, personnel or student records, and those with access to student housing or university vehicles. As fully documented by Dickerson (2008), highly publicized cases have forced university administrators and state legislators to reconsider the role of criminal background checks, not only in hiring procedures, but also in the matriculation of students (Hughes \& White, 2006). In addition to the 2007 mass murders by Seung-Hui Cho at Virginia Tech, Dickerson details 13 significant violent crimes on campus since 2002, including the separate murders of Jessica Faulkner and Christina Naujoks within a month of each other at UNC-Wilmington in 2004. Both alleged killers had criminal records. The murder of Jessica Faulkner was particularly egregious because the fellow student who confessed to her murder, Curtis Dixon, the son of a UNC administrator, had a "well documented history of violence against women, including incidents at other UNC campuses" (Dickerson, 436). Curtis Dixon's father allegedly completed his son's application to UNC Wilmington, and did not respond accurately with information about his son's past criminal and disciplinary history in the self-disclosure questions. Since 2008, additional high profile crimes on campus have included Yeardley Love's murder by fellow student and lacrosse player, George Huguely, and the death of Dominque Frazier at Bowie State University.

\subsection{State Mandates}

In all, there have been a total of five states that have either passed legislation or implemented mandates requiring new hires (including new student hires in some cases) to undergo criminal background checks prior to being hired into the organization: Arizona (2005), Kentucky (2006), Wisconsin (2006),North Carolina (2007), North Dakota (2007), and Utah (2007). Spurred on by the UNC-Wilmington murders, there have been two additional states (North Carolina and Virginia) that have considered, and/or, passed legislation aimed specifically at checking the criminal history/background of incoming students.For this study, we have chosen the Clery data from the state universities of Arizona, Kentucky, Utah and Wisconsin for a preliminary analysis of the impact of mandated background checks on the rate of criminal activity on campus. See Appendix B for a full overview of the various legislative or Board of Regents-mandated efforts by each state.

\section{Methodology}

\subsection{Model and Variables Defined}

\subsubsection{Dependent Variables}

This study attempts to measure the effectiveness of background check practices at reducing the rate of criminal activity on college campuses. For the dependent variable of campus crime, we utilized the Department of Education's (DOE) website that is responsible for collecting and maintaining all Clery Act data for all public and private institutions. The data are available for download from the Department's website, the Campus Safety and Security Data Analysis Cutting Tool maintained by the Office of Postsecondary Education of the U.S. Department of Education (http://ope.ed.gov/security). Clery Act statistics for all 4-year public institutions were collected in the four states, included in this analysis, for the three years before and, at a minimum, three years after implementation of background check requirements. Data for the year of implementation was utilized to provide a "base" year of analysis and distinguish between pre-background check data and post-background check data.

According to the DOE website, "The data are drawn from the OPE Campus Safety and Security Statistics website database to which crime statistics and fire statistics (as of the 2010 data collection) are submitted annually, via a web-based data collection, by all postsecondary institutions that receive Title IV funding (i.e., 
those that participate in federal student aid programs)." To reiterate, the crime statistics reported through this tool are not necessarily entirely representative of the actual criminal activity occurring on college campuses as they represent only reports of criminal instances, not prosecutions or convictions of the alleged crimes.Other crimes may be significantly under-reported because "neither schools nor victims report all relevant criminal activity, particularly with regard to sexual assaults" (Dickerson, 428). Finally, the Clery Data are not comparable to the FBI data collected for the campus area either because "some statistics are provided by non-police authorities and, as such, the data are not directly comparable to data from the FBI's Uniform Crime Reporting System which only collects statistics from police authorities" (U.S. Department of Education, 2013). Despite these caveats, the data are considered the best available source to compare reported criminal activity across individual higher education institutions.

The statistics cover the following criminal offenses: criminal homicide, including murder, negligent and non-negligent manslaughter, forcible and non-forcible sex offenses, robbery, aggravated assault, burglary, motor vehicle theft, and arson. The definition and coding of these crimes is taken directly from the FBI's Uniform Crime Reporting Handbook (UCR) and ensures that the categorization of reported crimes by each school follows a standardized process. We only include criminal offenses that occurred on campus in an effort to make comparisons more valid across institution type and location. We also did not include the campus statistics for drug and alcohol and firearms disciplinary violations in this analysis because these can differ substantially by state or local jurisdictions. This would make comparisons across states and institutions difficult since there would not be a common standard for how these data are collected.We compiled and analyzed the criminal offense data by individual state because there is variability among states' policies (and, independently, in some states, each Board of Regents). Dates of implementation also vary, not only by year, but also by month, differentials that contributed to incorporating the year of implementation as the base year with all data collected before that year considered "pre-background check" years, and all data collected after that year considered "post-background check" data. Additionally, the Clery Act reports lag the reporting cycle by one year. So, for example, the 2011 Clery Act report for a college will present data from 2010, 2009 and 2008 (because schools are required to report data from the previous three years). We have therefore used as many years of post-implementation data as are available from the Clery Reports. The data were compiled by controlling for student population and is reported as a "rate per 1,000 students."

Given the findings of Hart (2003) and Baum and Klaus (2005) that the type of crime actually impacts the likelihood of whether an individual will report the crime or not, we also decided to disaggregate the type of Clery Act, by violent and non-violent categories of criminal activity.As such, the total Clery Act numbers were divided by total student population to get a "rate per 1,000 students" for both the violent and non-violent Clery incident totals, providing two more dependent variables for analysis.

\subsubsection{Independent Variables}

The background check data, including information on the robustness or quality of the check were collected in two ways. First, the individual schools' human resources websites were accessed to get a copy of the school's background check policies.Despite the fact that the state has mandated these checks, each school actually has some control over their implementation resulting in variation in background check policies even among schools located in the same state. First, we reviewed the policies to capture the information related to our "robustness" variable. Secondarily, given the lack of specific detail in some written policies, we contacted individuals within each human resources department for each school covered in this analysis for clarification of the details of their respective policy implementation. If schools conduct background checks, it is hypothesized that there will be lower levels of Clery Act incidents overall for two reasons. First, background check practices will discover individuals with less reputable backgrounds, as they are trying to become employed by an organization, and whose behavior might cause the organization problems in the future. Second, it is possible that merely having a background check policy in place, no matter the level of robustness, will result in self-selection bias with fewer individuals with suspect backgrounds applying to the organization in the first place because they fear being identified as a criminal. This leads to the following hypothesis:

\section{Hypotheses}

Hypothesis 1: Schools will experience lower levels of Clery incidents in the years post background check implementation than they did in the years prior to the background check implementation.

Schools that had background check policies in place at a particular point in time were given a designation of "1" while schools that did not have a policy in place in an identified year were coded a " 0 ."

The "robustness" of the background check policy is hypothesized to play a significant role in reducing the 
overall number of Clery Act incidents because it will likely result in a higher number of overall checks being run and, quite possibly, more quality background check information being produced, leading to more informed hiring decisions. There are some data suggesting that background check databases are often plagued by significant data entry error along with significant processing delays in actually getting the criminal data into the database to be searched (Winston, 2005). So companies utilizing just a database check are taking far greater negligent hiring risks (the risk of hiring someone who poses an actual danger to employees and customers), than organizations who rely on both database checks and county courthouse checks. This reasoning leads to our second hypothesis:

Hypothesis 2: Schools with more robust background check policies will experience lower levels of Clery incidents than schools with less robust background check policies.

The robustness variable was coded by one of the authors who has done extensive research in the area of background check policies within higher education, and also founded a company that provides criminal background checks to corporate, higher education, and non-profit markets. The policies were graded as follows:No check $=0$; Basic (includes just a social security number trace and a national criminal database check) $=1$; Competitive (includes social security number trace, sex offender database check and/or national criminal database check anda county level criminal check) $=2$; Robust (includes a social security number trace, national criminal database check and sex offender database check and a county level criminal check and/or fingerprint checks plus additional checks) $=3$. We assume that the more robust background check policies are more likely to detect problems in a candidate's background than the less robust policies, and therefore mitigate crime more effectively.

\section{Analysis Description}

Multi-factor, repeated-measures, partially-nested ANOVA model is appropriate to the analysis of this design because we are interested in whether there are changes in the Clery Act rates over time due to a pre-treatment, post-treatment design in the utilization of background checks.Repeated-measures ANOVA is considered an appropriate technique for examining change over time when incorporating a pre- and post-treatment model design and when observing that these patterns of change vary for different groups (Urdan, 2010).We utilize three different response variables in this design including (1) Clery Incident Rate per 1,000 students; (2) Violent Clery Incident Rate per 1,000 students, and Non-Violent Clery Incident Rate per 1,000 students. We also include the following primary factors:Background Check Type, School (which is incorporated as a random factor nested within Background Check Type), Measurement Time (Pre-test, implementation, post-test),and Year (nested within Measurement Time).

We also included the following secondary factors: state and location. These had to be analyzed separately, due to empty cells (i.e. some states/locations that did not have any of a certain check type). Therefore we ran separate (but identical) models with each of these variables in lieu of check-type to see what impact the state and geographical locationmight have on the Clery incident levels. Finally, we had considered using FBI crime data collected by location of school as a covariate in our model to account for location effects, but ultimately decided that the "school" variable was a more efficient way to capture more of the location and school-specific variation that just the use of FBI data on its own.

\section{Results}

Our model contains the following terms which are labeled with letters for simplicity:

$\mathrm{A}=$ School (30 levels)

$\mathrm{B}=$ Year (7 levels)

C: Time (three levels....1: prior to implementation, 2: implementation, 3: post implementation)

D: Check type (1, 2, 3, with 3 being the highest or most robust check)

The $C^{*} \mathrm{D}$ interaction term is what allows us to compare the prior and post implementation for each of the check-types. If no significance is found there, then effect $\mathrm{C}$ considers whether the background checks in general affect average Clery Incident levels, while effect $\mathrm{D}$ is a test of whether background checks in general make any difference to this being a nested model, effect $\mathrm{D}$ is tested over an error term which is a linear combination of MS(A(D)) and MS(Error). 
Table 3. ANOVA for the dependent variable: Clery overall crime

\begin{tabular}{llllll}
\hline SOURCE & DF & SS & MS & F-Value & P-value \\
\hline $\mathrm{D}$ & 2 & 5.72 & 2.86 & 2.36 & 0.1129 \\
$\mathrm{~A}(\mathrm{D})$ & 27 & 35.04 & 1.30 & 4.3 & $<.0001$ \\
$\mathrm{C}$ & 2 & 0.62 & 0.31 & 1.02 & 0.3627 \\
$\mathrm{C}^{*} \mathrm{D}$ & 4 & 1.62 & 0.41 & 1.35 & 0.2553 \\
$\mathrm{~B}(\mathrm{C})$ & 4 & 0.99 & 0.25 & 0.82 & 0.5153 \\
$\mathrm{~B} * \mathrm{D}(\mathrm{C})$ & 8 & 1.02 & 0.13 & 0.42 & 0.9054 \\
Error & 162 & 48.89 & 0.30 & & \\
\hline
\end{tabular}

Since it is necessary to demonstrate first the significance of the interaction effect $(c * d)$ before considering $\mathrm{c}$ and $\mathrm{d}$ effects separately, we first test $\mathrm{H} 2$ (interaction effect) and then $\mathrm{H} 1$ (c and d separately).

\subsection{Total Clery Incidents and Background Check Type (H.2)}

For the total Clery Incident Rate, there is no evidence of a pre/post difference in average incident rate for any check-types (basic, competitive, robust): $\mathbf{F}(\mathbf{4 , 1 6 2})=\mathbf{1 . 6 2} ; \mathbf{p}$-value $=\mathbf{0 . 2 5 5 3}$.As such, Hypothesis 2 , which suggested that for schools with more robust background checks will experience lower levels of Clery incidents post-background check implementation, is not supported.

We also ran the analysis for both the Violent Clery Incident and the Non-Violent Clery Incident Rate to see if there were differences based on the type of crime as prior literature had suggested these rates might differ substantially on college campuses. As with our prior findings on the Overall Clery Incident Rate, when we break down the Clery Incident Rate by Violent and Non-Violent Incident Rates, we find little evidence of any pre/post difference in incident rates by type of check.Specifically, for the Violent Clery Incident Rate, there is no evidence of a pre/post difference in average incident rate for any check-types (basic, competitive, robust): $\mathbf{F}(\mathbf{4 , 1 6 2})=\mathbf{1 . 1 1} ; \mathbf{p}$-value $=\mathbf{0 . 3 5 5 5}$. For the Non-violent Clery Incident Rate, there is also no evidence of a pre/post difference in average incident rate for any check-types (basic, competitive, robust): $\mathbf{F}(\mathbf{4 , 1 6 2})=\mathbf{0 . 5 4}$; p-value $=\mathbf{0 . 7 0 5 5}$.

\subsection{Total Clery Incidents and Background Check (H.1)}

For the total Clery Incident Rate, there is no evidence of a pre/post difference in average incident rate for schools that implemented background checks: $\mathbf{F}(\mathbf{4 , 1 6 2})=\mathbf{0 . 6 1 6 0 4 6}$; p-value $=\mathbf{. 3 6 2 7}$. As such, Hypothesis 1 which suggested that there will be lower levels of Clery incidents post-background check implementation is not supported.

\subsection{Clery Incidents by State}

For the Total Clery Incident Rate, there is evidence that pre/post average incident rates differ in some of the states: $\mathbf{F}(\mathbf{6 , 1 6 2})=\mathbf{3 . 4 7} ; \mathbf{p}$-value $=\mathbf{0 . 0 0 3 0}$. However, Tukey intervals are really not informative either as there is no evidence of a difference from these for any state, but Kentucky shows a possible increase up to 0.9 observed in that state. For Violent Clery Incident Rates, there is no evidence of a pre/post difference in average incident rate for any state: $\mathbf{F}(\mathbf{6 , 1 6 2})=\mathbf{1 . 8 9} ; \mathbf{p}$-value $=\mathbf{0 . 0 8 5 5}$. Additionally, based on Tukey adjusted confidence intervals, the largest difference that might have been missed by this analysis is of size only about 1.3.Finally, for Non-violent Clery Incident Rates, there is evidence that pre/post average incident rates differ in some of the states. $\mathbf{F}(\mathbf{6 , 1 6 2})=\mathbf{2 . 9 7} ; \mathbf{p}$-value $=\mathbf{0 . 0 0 9 0}$. Once again, Tukey intervals are not really informative as there is no evidence of a difference from these for any state.However, both Kentucky and Wisconsin seem to be of some interest, with the possibility of an increase up to 0.9 is observed in Kentucky and a decrease up to 1.85 in Wisconsin.

We attempted one final model where both check-type and state were included in the same model.This model is imbalanced; with some zero cells (for example AZ had only check-types 2 and 3,

\begin{tabular}{|c|c|c|c|c|}
\hline Type & AZ & KY & UT & WI \\
\hline 1 & 0 & 1 & 2 & 1 \\
\hline 2 & 1 & 3 & 1 & 3 \\
\hline 3 & 2 & 4 & 3 & 9 \\
\hline
\end{tabular}
not 1).This creates issues in modeling and makes interpretation difficult if not impossible.However, when we run this ANOVA repeated measures on this model, we do note from this model a significant interaction between 
check-type (basic, competitive and robust)and State in comparison across pre-post values (for Clery overall): $\mathbf{F}(\mathbf{1 6}, 146)=\mathbf{2 . 1 9}, \mathrm{p}$-value $=\mathbf{0 . 0 0 7 7}$

\section{Implications}

These results preliminarily suggest that the implementation of background check policies and practices on university campuses has not had a significant impact on reducing the total number of Clery Act reports compiled by these institutions on an annual basis.More specifically, in testing for whether the quality of the background check matters, for the three models utilizing background check type as the independent variable and Clery IR overall, Clery IR Violent and Clery IR Non-violent as the dependent variables, there was also no significant impact on reducing the total number of Clery incidents.

While these two results might be surprising at first, there are some possible explanations for why these results make some sense. First, it is difficult to test for the effect of avoiding something that never happened. If the presence of background checks prevented universities from hiring someone with a criminal background who might have caused harm to the campus population later on, then we can argue that the policy has been effective despite not having the raw numbers to back it up. Unfortunately, most organizations do not keep records of how many individuals they deny admission or employment to because of a failed background check. Current Fair Credit Reporting Agency (FCRA) guidelines encourage employers to get rid of background check results as "expeditiously" as possible to prevent the data from being accessed by unauthorized individuals so there is no motivation on the part of employers to maintain these records. Additionally, due to federal and state laws banning the blanket denial of individuals with criminal backgrounds from being employed, most organizations have gone to a committee-based system that encourages a discussion around accepting individuals with criminal backgrounds as long as the crime(s) committed meet certain criteria (Note 5). This would result in individuals with criminal records actually being employed by institutions as long as their criminal record was not related to the work they will do in the job they are hired into.An additional explanation may be the likelihood of self-selection bias. Individuals with criminal backgrounds will avoid organizations and institutions where they know they will undergo a background check and instead will seek employment at other organizations that do not utilize background check practices.

When we take into account the impact of state on Clery incident numbers, there is evidence that pre/post average overall Clery incidents and Non-violent Clery incidents do differ by states with incidents in Kentucky increasing in the years immediately following post-background check implementation and Clery incidents in Wisconsin decreasing in the years immediately following post-background check implementation. These results are certainly impacted by the very small sample sizes of the study and so we have to be very careful about making inferences about the impact of the state on Clery incident levels since we already checked and found no differences in Clery incidents based on the type of background check utilized. Nonetheless the results represent some potentially interesting data that should be further investigated once more states begin to legislate or more Boards of Regents begin to mandate the use of background checks. For example, if we look at the four states included in our analysis, Wisconsin has the highest numbers of campuses $(69 \%)$ employing the most robust background check available while Kentucky deploys the most robust check much less frequently $(50 \%)$.Additionally, 12 of $13(92 \%)$ of Wisconsin schools will repeat the background check process within 4 years of the date of hire while Kentucky had no schools $(0 \%)$ that repeat the background check process during any time frame unless that individual moves to a new position within the university. These facts would seem to suggest that, over a longer period of time, we should expect to see increased differences in Clery incidents between state schools which are impacted by these different policies.

\section{Limitations}

\subsection{Macro Environment}

There may also be factors in the macro environment that contribute to a decline in reported crime statistics at some universities that may be unrelated to the utilization of background checks. Overall crime rates in the United States have been declining for at least ten years. The data in Table 4 distinguish between violent crime and personal property crime (Note 6). According to the FBI's estimates, in 2010, an estimated 1,246,248 violent crimes occurred nationwide, a decrease of 6.0 percent from the 2009 estimate. The 2010 estimated violent crime total was 13.2 percent below the 2006 level and 13.4 percent below the 2001 level.Given this data, the reduction in Clery Act reports could be a reflection of a broader societal trend of declining crime rates, rather than the direct result of background checks. 
Table 4. National crime statistics, 2001-2010

\begin{tabular}{llllll}
\hline Year & Population & Violentcrime & Violentcrimerate & Propertycrime & Propertycrimerate \\
\hline 2001 & $285,317,559$ & $1,439,480$ & 504.5 & $10,437,189$ & $3,658.1$ \\
2002 & $287,973,924$ & $1,423,677$ & 494.4 & $10,455,277$ & $3,630.6$ \\
2003 & $290,788,976$ & $1,383,676$ & 475.8 & $10,442,862$ & $3,591.2$ \\
2004 & $293,656,842$ & $1,360,088$ & 463.2 & $10,319,386$ & $3,514.1$ \\
2005 & $296,507,061$ & $1,390,745$ & 469.0 & $10,174,754$ & $3,431.5$ \\
2006 & $299,398,484$ & $1,435,123$ & 479.3 & $10,019,601$ & $3,346.6$ \\
2007 & $301,621,157$ & $1,422,970$ & 471.8 & $9,882,212$ & $3,276.4$ \\
2008 & $304,059,724$ & $1,394,461$ & 458.6 & $9,774,152$ & $3,214.6$ \\
2009 & $307,006,550$ & $1,325,896$ & 431.9 & $9,337,060$ & $3,041.3$ \\
2010 & $308,745,538$ & $1,246,248$ & 403.6 & $9,082,887$ & $2,941.9$ \\
\hline
\end{tabular}

\subsection{Clery Data as a Metric}

While the results suggest some interesting patterns among the schools with regard to their overall Clery incident levels, this is a preliminary study, with many caveats. The results are not uniform, represent only a handful of public institutions in four states, and use only a few years' data available for analysis. The variations between states in their policies, and within states, between institutions, in their implementation of state mandates, may account for confounding results. While limited in its generalizability, the results for Wisconsin schools suggest that the quality of the background check may also account for the variation in results. Additionally, given the fact that prior research suggests Clery Act statistics under-represent the actual amount of crime occurring on college campuses cannot be ignored. So, it is possible that the use of Clery Act statistics may be the wrong metric to assess whether background checks actually work to reduce crime on campus. While no immediate answers can be derived from the current findings, what is clear is that the implementation of background check policies is clearly not a panacea for reducing campus crime and that much more needs to be done to reduce crime rates on college campuses to truly achieve the vision behind the original Clery Act.

Finally, and maybe most importantly, it is also possible that Clery Act reports may be the wrong metric to assess the effectiveness of the background check policies that only cover employees of the institutions, which will sometimes covers student employees, but generally does not cover all students. Because Clery incidents do not capture the "who" behind the alleged crime being committed, coupled with the insignificance of new employee hire background check practices at reducing campus crime, could suggest that staff and faculty are generally not the "who" behind the Clery incident numbers on campus. As Nobles et al. (2010) has reported, a significant amount of Clery Act reports represent student-on-student crime, so the use of Clery Act data to assess the effectiveness of "employee-only" policies covered in this analysis may be inadequate. While a strong argument can be made for assuming that schools that do background checks are also likely to be engaged in other types of risk mitigating activities that should lead to lower Clery Incident levels, the fact that this does not appear to be represented by the study results may have inadvertently provided further evidence of the "student-centered" nature of the Clery data.

\section{Future Research}

The variability in results, by state, and by institutions within states, suggests further research is needed regarding individual institution's policies and practices in their recruitment processes. The fact that background check activities continue to emerge as a risk mitigation tool on college campuses suggest that future research may benefit from increasing sample sizes and access to richer contextual data around this topic.

The lack of significance in the relationship between background checks and Clery incidents does not diminish the importance of the need to continue to enhance the data collection process and subsequent impact of the Clery Act on college campuses.For example, is the significant under-reporting of campus crimes due to a lack of education and awareness? Or due to the lack of a more thorough data collection process? While there are significant and obvious issues with the Clery Act, there are opportunities to improve processes around the Act that would significantly improve the overall impact of the Act on ensuring safer college campuses. For example, Gregory and Janosick (2002) offered recommendations on how to improve the Clery Act including: that campus 
safety is the responsibility of the entire campus including both external and internal constituents, that funding should be available to reinforce Clery and the activities associated with improving campus safety, an office of Clery Act compliance should be launched and housed in the Department of Education, that to allow universities time to fully understand the Act, no new regulations and/or amendments and no punishment for violations should occur for a specified period of time, that research on the Clery Act should be encouraged, and that Congressional support and support from the Department of Education should be sought for campus safety measures.

Whatever the flaws in determining who is actually represented by Clery Act reports, the Clery data will continue as a useful tool to analyze the impact of state and university policies on the reduction of crime on campus in future years. This is especially true of the final research topic raised by this study.Background checks currently only address employees (that may include some students), but not students as a population. Yet student-on-student crime may be the most significant safety problem in higher education. A new type of admissions process may be necessary to reduce that category of crime because traditional background checks typically are not useful to profile 18-21 year-olds due to the fact that the vast majority of the data potentially available might be protected by the juvenile status of the student. One emerging area of potential research could be the use of social media background checks which involve the evaluation and analysis of an individual's social media profiles to identify any areas of concern that an individual may pose a threat to themselves or others. Social media checks are increasingly being used by employers to evaluate individuals for their potential fit with employers. While many in the legal profession warn employers against utilizing social media checks given the underdeveloped legal precedents around this topic, the use of these sites by HR managers is definitely on the rise. A recent survey by CareerBuilder found $37 \%$ of employer respondents admitted to using social media sites to screen job candidates (Rhodes, 2012). The effectiveness of any such student-centered "background" checking could also be analyzed using the Clery data.

\section{Acknowledgements}

A special thank you is extended to the following individuals for their assistance on the statistical analysis of the data included in this research:Richard E. Hughes, Professor of Particle and AstroParticle Physics, The Ohio State University; Philippe Byosiere, Doshisha Business School, Japan; Joseph Nolan, Associate Professor of Statistics and Craig Heard, The Burkardt Consulting Center, Northern Kentucky University.

\section{References}

American Association of University Professors. (2004). Verification and trust:Background investigations preceding faculty appointments. Produced by Committee A on Academic Freedom and Tenure.

Baum, K., \& Klaus, P. (2005).Violent victimization of college students 1995-2002. Washington, D.C.: Bureau of Justice Statistics. Retrieved from http://www.bjs.gov/content/pub/pdf/vvcs02.pdf

Brinkley, W. C., \& Lester, J. D. (2003).Campus crime in Missouri: An analysis and comparison of crime in four-year colleges and universities. Journal of Security Administration, 26(1), 1-15.

Brubaker, S. J. (2009). Sexual assault prevalence, reporting and policies: Comparing college and university campuses and military service academies. Security Journal, 22(1), 56-72. http://dx.doi.org/10.1057/sj.2008.10

Carr, J. L. (2007, March/April). Campus violence white paper. Journal of American College Health, 55, 304-319. http://dx.doi.org/10.3200/JACH.55.5.304-320

Connerley, M. L., Arvey, R. D., \& Bernardy, C. J. (2001). Criminal background checks for prospective and current employees: Current practices among municipal agencies. Public Personnel Management, 30(2), 173-183.

Criminal background checks of prospective and existing employees of higher education institutions, Utah Code, §3B-1-110. (2007).

Dickerson, D. (2008). Background checks in the university admissions process: An overview of legal and policy considerations. Journal of College and University Law, 34(2), 419-505.

Federal Trade Commission. (2013). Fair Credit Reporting Act. Retrieved December 1, 2013, from http://www.ftc.gov/os/statutes/031224fcra.pdf

Fingerprinting academic and nonacademic personnel, Arizona Revised Statutes § 15-1649. (2005).

Fingerprinting academic and nonacademic personnel, Arizona Revised Statutes § 15-1649. (2005).

Fisher, B. S., Cullen, F. T., \&Turner, M. G. (2002).Being pursued: Stalking victimization in a national study of 
$\begin{array}{lllll}\text { college women. Criminology and Public Policy, } & \text { 257-308. }\end{array}$ http://dx.doi.org/10.1111/j.1745-9133.2002.tb00091.x

Fisher, B. S., Hartman, J. L., Cullen, F. T., \& Turner, M. G. (2002).Making campusessafer for students: The Clery Act as a symbolic legal reform. Stetson Law Review, 32, 61-89.

Fleenor, M. W. (2009). A quantitative analysis of crime rates in American colleges with and without residential college systems. Dissertation.UMI Number 3361643.

Gregory, D. E., \& Janosick, S. M. (2002). The Clery Act: How effective is it? Perceptions from the field-the current state of the research and recommendations for improvement. Stetson Law Review, 32, 7-59.

Hart, T. C. (2003). Violent victimization of college students, 1995-2000. Washington, D.C.: Bureau of Justice Statistics. (NCJ 196143).

Hart, T. C. (2007). The violent victimization of college students: Findings from the national crime victimization survey. In B. S. Fisher, \& J. J. Sloan (Eds.), Campus Crime: Legal, Social and Policy Perspectives (2nd ed., pp. 129-146). Springfield, IL: Charles C. Tomas.

Havlik v. Johnson \& Wales, 509 F.3d 25. ( $1^{\text {st }}$ Cir. 2007).

Hughes, S. F., \& White, R. J. (2006).Risk Mitigation in Higher Education: An Overview of the use of background checks on campus. CUPA-HR Journal, 57(2), 23-32.

Hughes, S. F., Hertz, G., \& White, R. J. (2013). Criminal Background Checks in U.S. Higher Education: A Review of Policy Developments, Process Implementations and Post-Results Evaluation Procedures. Public Personnel Management, 42, 421-437. http://dx.doi.org/10.1177/0091026013495763

Institutional and financial assistance information for students, 20 U.S.C. $\$ 1092$. (2008).

Jacobs, P. (2013). Murdered UMich medical student died from a gunshot wound. Business Insider. Retrieved from http://www.businessinsider.com/murdered-umich-medical-student-died-from-a-gunshot-wound-2013-7

Kahland v. Villarreal, 155 P.3d 491. (Colo. Ct. App. 2006).

Locklear, R. J. (2003). Policy alone is not a deterrent to violence. The NCAA News. Retrieved from http://fs.ncaa.org/Docs/NCAANewsArchive/2003/Editorial/policy\%2Balone\%2Bis\%2Bnot\%2Ba\%2Bdeter rent $\% 2 \mathrm{Bto} \% 2 \mathrm{Bviolence} \% 2 \mathrm{~B}-\% 2 \mathrm{~B} 5-26-03$.html

Merten, M. J. (2008). Acceptability of dating violence among late adolescents: The role of sports participation, competitive attitudes, and selected dynamics of relationship violence. Adolescence, Spring, 43, 31-55.

Nobles, M. R., Fox, K. A., Khey, D. N., \& Lizotte, A. J. (2010). Community andcampus crime: A geospatial examination of the Clery Act. Crime \& Delinquency. Retrieved from http://cad.sagepub.com/content/early/2010/08/26/0011128710372188

Pearson, S. (2013). Penn State's tab for Sandusky scandal exceeds $\$ 50$ Million. Bloomberg.Retrieved from http://www.bloomberg.com/news/2013-10-14/penn-state-says-managing-sandusky-scandal-has-cost-50-5million.html

Peterson's Guide to 4-year Colleges (2002, 2003, 2004, 2005, 2006, 2007, 2008, 2009, 2010, 2011).

Public institution of postsecondary education criminal history background checks, Kentucky Revised Statutes $\S$ 164.281 (2006).

Rhodes, K. (2012). New laws protect social media privacy. Region Focus, $4^{\text {th }}$ quarter, 9.

Schloss, L. M., \& Lahr, J. G. (2008). Smart hiring and proper background checks. Employee Relations Law Journal, 34(3), 46-71.

Sloan, J. J., Fisher, B. S., \& Cullen, F. T. (1997). Assessing the student right-to-know and campus security act of 1990: An analysis of the victim reporting practices of college and university students. Crime \& Delinquency, 43, 148-168. http://dx.doi.org/10.1177/0011128797043002002

Smith, D., \& Stewart, S. (2003). Sexual aggression and sports participation. Journal of Sport Behavior, 26(4), 384-395.

Stoll, M. A., \& Bushway, S. D. (2008).The effect of criminal background checks on hiring ex-offenders. Criminology \& Public Policy, 7(3), 371-404. http://dx.doi.org/10.1111/j.1745-9133.2008.00516.x

U.S. Department of Education Crime Statistics Online (2013). Retrieved October 16, 2013, from http://www2.ed.gov/admins/lead/safety/campus.html\#regs 
U.S. Department of Education. (2013). The Campus Safety and Security Data Cutting and Analysis Tool. Retrieved from http://ope.ed.gov/security/

University of Wisconsin System Criminal Background Check Policy, §20-19 (2006).

Urdan, T. (2010). Statistics in Plain English (3rd ed.). Routledge, Taylor \& Francis Group, New York, London.

Waska, W. (2007). Legal issues for HR professionals: Reference checking/background investigations. Public Personnel Management, 36(1), 79-89.

Winston, C. (2005). The National Crime Information Center: Review and evaluation.Prepared on behalf of the National Association of Professional Background Screeners (NABPS). Retrieved from http://www.justice.gov/olp/pdf/ncicteportjuly25.pdf

\section{Notes}

Note 1. "Claims for negligent hiring or retention can result from an employer's failure to discover that the employee created an undue risk of harm to others."Kahland v. Villarreal, 155 P.3d 491, 493 (Colo. Ct. App. 2006) (citing Connes v. Molalla Transp. Sys., Inc., 831 P.2d 1316 [Colo. 1992]).

Note 2. "Title VII of the Civil Rights Act of 1964 (Title VII) prohibits employers from discriminating against individuals, at any stage of employment, on the basis of race, color, religion, sex or national origin" (42 U.S.C. 2000 e, et seq.).As such, "Claims under Title VII are generally pursued under one of two distinct theories, disparate treatment or disparate impact. Disparate treatment is generally associated with claims of intentional discrimination. Disparate impact claims often arise when an employer's practices or procedures, which are not intentionally discriminatory, adversely impact individuals protected by the statute." Hughes, S. F., Hertz, G., and R. J. White (2012). "Criminal Background Checks in U.S. Higher Education:A Review of Policy Developments, Process Implementations and Post-Results Evaluation Procedures," Public Personnel Management. Pending.

Note 3. FCRA requires employers to gain informed consent from potential employees that a background check will be conducted and governs the processes around how the check will be implemented and the results evaluated. (20 U.S.C. 1232g; 34 CFR Part 99).

Note 4. Commonly referred to as the "General Duty Clause," this clause requires that an employer provide a workplace free of "recognized hazards that are likely to cause death or serious physical harm to employees." Schloss, L. M., Lahr, J. G. (2008). "Smart Hiring and Proper Background Checks," Employee Relations Law Journal, Vol. 34, No. 3 (Winter), pp.46-71.

Note 5. EEOC guidelines have recently been updated to prevent blanket use of criminal background check results as a reason to deny employment to candidates with records.These new, and much stricter, guidelines require employers to show why an individual's criminal record may be a limiting factor to their employment.

Note 6. 2012. FBI's Uniform Crime Reporting Program defines violent crime as "composed of four offenses: murder and non-negligent manslaughter, forcible rape, robbery, and aggravated assault. Violent crimes are defined in the UCR Program as those offenses which involve force or threat of force."

\section{Appendix A}

\section{The Clery Act}

The information to be collected and distributed through the Clery Act legislation includes "how to report criminal actions or other emergencies occurring on campus and institutional response to these reports, security and access issues regarding campus facilities, including campus residences, policies concerning campus law enforcement programs designed to inform students and employees about campus security.... and to encourage students and employees to be responsible for their own security and the security of others, programs designed to inform students and employees about the prevention of crimes, crime statistics involving murder; rape; robbery; aggravated assault; burglary and motor vehicle theft, policies regarding off-campus student organizations, arrest statistics involving liquor law violations, drug abuse violations, and weapons possessions, and policies regarding alcohol and drugs" (www.securityoncampus.org).Congress then stated that students and employees at colleges and universities should know the "incidence of crime" and how to prevent and report crime, and college applicants and their parents should also "have access" to this information (www.securityoncampus.org).

Congress, in this Act, allows discretion in devising the required policies. Congress requires, however, that "timely reports" must be made "to the campus community on crimes considered to be a threat..." Finally, upon 
request, a copy of the above statistics must be compiled so a report on "campus crime statistics" may be given to "the Committee on Education and Labor of the House of Representatives and the Committee on Labor and Human Resources of the Senate" and also "identify exemplary" policies "and disseminate information concerning those policies...that have proven effective in the reduction of campus crime" (www.securityoncampus.org).

The "Jeanne Clery Act" was amended, and as amended through 2008, specific crimes were added to the list of those to be reported to campus security: "sex offenses, forcible or nonforcible; manslaughter; and arson" (Institutional and financial assistance information for students, 2008). The category "rape" was changed to "sex offenses, forcible and nonforcible" (Institutional and financial assistance information for students,2008). The amended Act now specifically states that the statistics compiled "shall not identify victims of crimes or persons accused of crimes" (Institutional and financial assistance information for students, 2008). The amended Act provides that colleges and universities must also include a statement in the required annual report "advising the campus community where law enforcement agency information provided by a State...concerning registered sex offenders may be obtained" (Institutional and financial assistance information for students, 2008).

In a nod to current technology as well as recent campus violence, the Act also requires the report to include "A statement of current campus policies regarding immediate emergency response and evacuation procedures, including the use of electronic and cellular communication (if appropriate), which policies shall include procedures to-(i) immediately notify the campus community...(ii) publicize [these] procedures on an annual basis...(iii) test...on an annual basis" (Institutional and financial assistance information for students, 2008).

The amended Act also requires any college of university covered by this Act that "maintains a police or security department" to "maintain a daily log...recording all crimes reported" (Institutional and financial assistance information for students, 2008). This log must be "open to public inspection within two business days of the initial report" unless "disclosure of such information is prohibited by law or such disclosure would jeopardize the confidentiality of the victim" (Institutional and financial assistance information for students, 2008). The information in this log is to be updated as appropriate, but "information may be withheld" if "release of such information would jeopardize an ongoing criminal investigation or the safety of an individual, cause a suspect to flee or evade detection, or result in the destruction of evidence" (Institutional and financial assistance information for students, 2008).

In the earlier incarnation of the Act, the appropriate government agency was to report to the Committee on Education and the Workforce of the House of Representatives and the Committee on Labor and Human Resources of the Senate and this requirement has been deleted and "authorizing committees" replaces that language (Institutional and financial assistance information for students, 2008). This section now also requires that "copies of the statistics submitted to the Secretary [be made] available to the public" (Institutional and financial assistance information for students, 2008). The amended Act now specifically states that the statistics compiled "shall not identify victims of crimes or persons accused of crimes" (Institutional and financial assistance information for students, 2008).

The Act now includes a section on sexual assault. As part of the required report, each institution "participating in any program under this title shall develop and distribute... a statement of policy regarding - (i) ...campus sexual assault programs, which shall be aimed at prevention of sex offenses; and (ii) the procedures followed once a sex offense has occurred" (Institutional and financial assistance information for students, 2008). The policy has to address "Education programs to promote the awareness of...sex offenses...possible sanctions...procedures students should follow if a sex offense occurs...procedures for on-campus disciplinary action...the accuser and the accused are entitled to the same opportunities to have other[s] present during a campus disciplinary proceeding...both the accuser and the accused shall be informed of the outcome...Informing students of their options to notify proper law enforcement authorities...Notification of students of existing counseling...services... Notification of students of options for...changing academic and living situations" (Institutional and financial assistance information for students, 2008).

The Act ends by stating that the crime statistics required have to distinguish amongst the criminal offenses that occur "on campus; in or on a non-campus building or property; on public property; and in dormitories or other residential facilities for students on campus" (Institutional and financial assistance information for students, 2008). If a college of university has "substantially misrepresented the number, location, or nature of the crimes to be required to be reported...the Secretary shall impose a civil penalty" (Institutional and financial assistance information for students, 2008). Thus, the Act includes a strong provision to ensure compliance which indicates the importance of the Act.The Act also requires a report to "the authorizing committees regarding compliance" 
and "the monitoring of such compliance" (Institutional and financial assistance information for students, 2008).

The Clery Act has also been interpreted by the courts. The court in Havlik v. Johnson \& Wales acknowledged that "each campus security office" has "substantial discretion" in fulfilling the notification requirement and that "school officials must act expeditiously to satisfy their responsibilities under the Clery Act" (Havlik v. Johnson \& Wales, 490 F. Supp. 2d 250 [D.R.I. 2007]).

\section{Appendix B}

\section{Arizona: Effective 2005}

Arizona statute 15-1649 requires that: "The finalist for a security or safety-sensitive position at a university that is under the jurisdiction of the Arizona Board of Regents shall be fingerprinted as a condition of employment. The finalist shall submit a full set of fingerprints to the university for the purpose of obtaining a state and federal criminal records check. The department of public safety may exchange this fingerprint data with the Federal Bureau of Investigation" (Fingerprinting academic and nonacademic personnel, 2005). Also, "A university may use information obtained pursuant to this section only for the purpose of evaluating the finalists for employment in security or safety-sensitive positions. A university may provide information received pursuant to this section to any other university that is evaluating the finalist for employment if the university is under the jurisdiction of the Arizona board of regents. A university may refuse to hire, may rescind an offer of employment to or may review and terminate the employment of a finalist or employee who has been convicted of or who has admitted committing any criminal offense. A university that is considering terminating an employee pursuant to this subsection shall provide due process to the employee in accordance with policies adopted by the Arizona board of regents and the university before taking disciplinary action" (Fingerprinting academic and nonacademic personnel, 2005). The law also protects universities from liability under this section and states that a "security or safety-sensitive position" must be identified as such "in the job description and in any advertisements for the position" (Fingerprinting academic and nonacademic personnel, 2005).

\section{Kentucky: Effective 2006}

Kentucky Revised Statutes (K.R.S.) 164.281 requires that: “(1) Each public institution of postsecondary education shall require a criminal history background check on all initial hires.

(a) The background check shall consist of a state criminal history background check and a national criminal history background check.

(b) Applications shall authorize the appropriate agency to search police records for convictions and make results known to the institution, and the institution may require the applicant to bear the cost of the criminal history background check" (Public institution of postsecondary education criminal history background checks, Kentucky Revised Statutes $\S 164.281,2006)$.

\section{Utah: Effective 2007}

Utah Code 53B-1-110 requires criminal background checks of employees of higher education institutions. This law requires that a policy be adopted providing for criminal background checks of "prospective employees" and "existing employees... where reasonable cause exists" (Criminal background checks of prospective and existing employees of higher education institutions, 2007).

The statute continues that "the policy shall require that an applicant for any position that involves significant contact with minors or any position considered to be security sensitive by the board or its designee shall submit to a criminal background check as a condition of employment" (Criminal background checks of prospective and existing employees of higher education institutions, 2007).

Also, "The policy may allow or require applicants for positions other than those described [above] to submit to a criminal background check as a condition of employment" and, "The policy may allow criminal background checks for new employees to be phased in over a two-year period" (Criminal background checks of prospective and existing employees of higher education institutions, 2007).

\section{Wisconsin: Effective 2007}

The University of Wisconsin System Board of Regents requires a criminal background check: “...it shall be the policy of the Board of Regents to require that a criminal background check be performed on each new hire for a UW System position. Criminal background checks shall be conducted on candidates recommended for hire, either prior to the extension of an offer of employment, or as part of an offer of employment that is made contingent upon 
a successful criminal background check" (University of Wisconsin System Criminal Background Check Policy, 2006). Also, each University of Wisconsin System “... institution shall develop a plan for implementing this policy, and submit it for initial approval to the UW System Office of Human Resources not later than May 1, 2007” (University of Wisconsin System Criminal Background Check Policy, 2006).

\section{Copyrights}

Copyright for this article is retained by the author(s), with first publication rights granted to the journal.

This is an open-access article distributed under the terms and conditions of the CreativeCommons Attribution license (http://creativecommons.org/licenses/by/3.0/). 